

\title{
Sequestration of As by iron plaque on the roots of three rice (Oryza sativa L.) cultivars in a low-P soil with or without $P$ fertilizer
}

Hu, Y., Li, J. H., Zhu, Y. G., Huang, Y. Z., Hu, H. Q., \& Christie, P. (2005). Sequestration of As by iron plaque on the roots of three rice (Oryza sativa L.) cultivars in a low-P soil with or without $P$ fertilizer. Environmental Geochemistry and Health, 27(2), 169-176. https://doi.org/10.1007/s10653-005-0132-5

Published in:

Environmental Geochemistry and Health

Queen's University Belfast - Research Portal:

Link to publication record in Queen's University Belfast Research Portal

\section{General rights}

Copyright for the publications made accessible via the Queen's University Belfast Research Portal is retained by the author(s) and / or other copyright owners and it is a condition of accessing these publications that users recognise and abide by the legal requirements associated with these rights.

Take down policy

The Research Portal is Queen's institutional repository that provides access to Queen's research output. Every effort has been made to ensure that content in the Research Portal does not infringe any person's rights, or applicable UK laws. If you discover content in the Research Portal that you believe breaches copyright or violates any law, please contact openaccess@qub.ac.uk. 


\title{
Sequestration of As by iron plaque on the roots of three rice (Oryza sativa $\mathrm{L}$.) cultivars in a low-P soil with or without $P$ fertilizer
}

\author{
Y. $\mathrm{Hu}^{1}$, J.-H. Li ${ }^{1}$, Y.-G. Zhu ${ }^{1,4}$, Y.-Z. Huang ${ }^{1}$, H.-Q. Hu ${ }^{2}$ \& P. Christie ${ }^{3}$ \\ ${ }^{1}$ Research center for Eco-environmental Sciences, Chinese Academy of Sciences, Beijing 100085, China \\ ${ }^{2}$ College of Environmental and Resource Sciences, Huazhong Agricultural University, Wuhan, China \\ ${ }^{3}$ Department of Agricultural and Environmental Science, Queen's University of Belfast, Newforge Lane, \\ Belfast BT9 5PX UK \\ ${ }^{4}$ Author for correspondence (tel.: + 86-10-62936940; fax: +86-10-62923563; e-mail:ygzhu@mail.rcees.ac.cn)
}

Received 11 June 2004; Accepted 5 November 2004

Key words: arsenic, iron plaque, Oryza sativa, rhizosphere, sequestration

\begin{abstract}
A pot experiment was carried out in a greenhouse to investigate the sequestration of As in iron plaques on root surface of three rice (Oryza sativa L.) cultivars. Phosphate (P) fertilization increased both plant biomass and tissue $\mathrm{P}$ concentrations significantly, indicating that the soils used in this study was highly P-deficient. Results from this study confirmed that low P supply improved the formation of iron plaque on rice roots. As a consequence, arsenic (As) concentrations in DCB-extracts with no P addition were significantly higher than those with $\mathrm{P}$ fertilization. Arsenic was highly sequestrated in iron plaque; arsenic concentration in iron was up to nearly $120 \mathrm{mg} \mathrm{kg}^{-1}$, while arsenic concentrations in roots were just several $\mathrm{mg} \mathrm{kg}^{-1}$. Both arsenic and phosphate concentrations in iron plaque were highly positively correlated with the amounts of iron plaque (DCB-extractable Fe). Contrary to normal understanding that increasing $\mathrm{P}$ supply could reduced As accumulation in plants, results from the present study showed that $\mathrm{P}$ fertilization did not inhibit the As uptake by plants (As accumulation in aboveground), which was probably due to the fact that iron plaque formation was improved under low $\mathrm{P}$ conditions, thus leading to more As sequestration in the iron plaque. Thus results obtained in this study indicated that the iron plaque may inhibit the transfer of As from roots to shoots, and thus alter the $\mathrm{P}-\mathrm{As}$ interaction in plant As uptake processes.
\end{abstract}

\section{Introduction}

Arsenic (As) is a highly toxic and carcinogenic ubiquitous metalloid and is widely distributed in the environment through both natural and anthropogenic pathways. Natural background levels of As are $5-6 \mathrm{mg} \mathrm{kg}^{-1}$ dry soil on average (Yan-Chu 1994). However, anthropogenic activities, such as pesticide use (Maclean \& Langille 1981), mining (Galbraith et al. 1995), or irrigation with contaminated groundwater (Abedin et al. 2002) have significantly enhanced As levels in the environment in some locations. Arsenic contamination of groundwater has been reported from many countries, with the most severe problems occurring in Bangladesh (Dhar et al. 1997; Biswas et al. 1998; Nickson et al. 1998; Chowdhury et al. 1999), West Bengal and India (Mandal et al. 1996, 1997), and China (Huang et al. 1992; Smith et al. 1992; Liangfang \& Jianghong 1994; Chen et al. 1995). The people of these regions not only drink contaminated groundwater but also use it for crop irrigation. In Bangladesh, irrigation is mostly dependent on groundwater and $75 \%$ of the total cropped area and $83 \%$ of the total irrigated area are irrigated using groundwater for rice cultivation (Dey et al. 1996). It has been reported that As levels in soils may reach over $80 \mathrm{mg} \mathrm{kg}^{-1}$ after irrigation with contaminated water (Ullah 1998) and may lead to a ten-fold elevation in grain As 
level (Meharg 2004). The local population may therefore be exposed to As contamination through two principal pathways, namely groundwatersoil-plant-human and groundwater-human (Juhaz et al. 2003).

Rice (Oryza sativa) is the staple food in many parts of the world, particularly in Southeast Asia. Rice grown on As-contaminated soils in China had high As levels in the grains (Xie \& Huang 1998). It was reported that in the vicinity of an As mine in Hunan, China, up to $35 \%$ of the local population had severe arsenism and the proportion increased with age (Wang et al. 1999). Epidemiological studies further demonstrated that there were significant correlations between As concentrations in human hair and those in local rice (Oryza sativa L.), wheat (Triticum aestivum L.) and soils (Lin et al. 2001). For populations living on subsistence rice diets the As contamination of rice grains contributes greatly to dietary As exposure. When drinking water levels of As are at the World Health Organization (WHO) limit of $10 \mu \mathrm{g} \mathrm{L}^{-1}, 0.05 \mathrm{mg} \mathrm{kg}^{-1}$ arsenic in rice contributes $\sim 60 \%$ of dietary As exposure. Rice with an As level of $1.8 \mathrm{mg} \mathrm{kg}^{-1}$ has been recorded in the As-affected tubewell areas of Bangladesh (Meharg 2004). Even at the very dangerous level of As in drinking water of $1 \mathrm{mg} \mathrm{L}^{-1}$, a rice arsenic level of $1.8 \mathrm{mg} \mathrm{kg}^{-1}$ contributes around $30 \%$ of dietary As intake (tips). Thus, As uptake by rice plants plays an important role in food chain transfer of this toxic element and poses health risks to human beings.

Iron plaque is commonly formed on the roots of aquatic plants such as Oryza sativa, Typha latifolia and Phragmites communis. The iron plaque may be amorphous or crystalline (Bacha \& Hossner 1977; Chen et al. 1980). It is composed mainly of ferrihydrite $(63 \%)$ with lesser amounts of goethite $(32 \%)$ and minor levels of siderite $(5 \%)$ (Hansel et al., 2001). It has been shown that iron plaque may be a barrier to the uptake of heavy metals such as $\mathrm{Cu}, \mathrm{Ni}, \mathrm{Mn}$ and $\mathrm{Cd}$ (Taylor \& Crowder 1983a; Otte et al. 1989; Greipsson 1994; Ye et al. 1998; Wang \& Peverly 1999). However, the overall effect of iron plaque on plant uptake of nutrients and/or contaminants may depend on the amounts of iron plaque formed on the roots (Otte 1987, 1989; Zhang et al. 1998). The functional groups of iron hydroxides may sequestrate some cations and anions (Kuo 1986; Otte et al. 1989).
Iron hydroxides in soil or solution had very strong binding affinity for As (V) (Meng 2002). Otte et al. (1991) showed that iron plaque played an important role in the uptake of As by the salt marsh plant Aster tripolium. Although the role of iron plaque on the roots has been investigated in recent years, the relationship between iron plaque and plant uptake of As is still under investigation.

In rice plants, iron plaque can be formed in both natural and laboratory conditions (Chen et al. 1980; Greipsson \& Crowder 1992; Greipsson 1994, 1995). The role of iron plaque on root surfaces of rice plants may be important for the development of practical approaches to reduce As uptake. Our previous experiments showed that iron plaque had a very strong affinity to As and enhanced uptake, but reduced the translocation of As from roots to shoots (Liu et al. $2004 a$, b). It has also been demonstrated that under solution culture conditions, low phosphate (P) supply may improve the formation of iron plaque leading to the sequestration of As on the root surface (Liu et al. 2004a). The aim of the present experiment was to investigate the effects of $\mathrm{P}$ fertilization on the amounts of iron plaque on the roots of three rice cultivars, on As sequestration in iron plaque and on As accumulation in the aerial plant parts.

\section{Materials and methods}

\section{Soil preparation}

A pot experiment was conducted using a highly weathered red soil taken from Huangshi, Hubei province, central China. After transport to the laboratory, the soil was air-dried and sieved ( $<2 \mathrm{~mm}$, stainless steel mesh) prior to analysis of chemical and physical properties. Selected soil properties analyzed according to the standard methods recommended by the Soil Science Society of China ( $\mathrm{Lu} \mathrm{1999)}$ are listed in Table 1. The soil was uniformly supplied with both $\mathrm{N}$ and $\mathrm{K}$ fertilizers at amounts equivalent to $200 \mathrm{mg} \mathrm{N} \mathrm{kg}^{-1}$ soil (as urea) and $133 \mathrm{mg} \mathrm{K}_{2} \mathrm{O} \mathrm{kg}{ }^{-1}$ (as $\mathrm{K}_{2} \mathrm{SO}_{4}$ ). Two $\mathrm{P}$ treatments were included in the experiment, namely no $\mathrm{P}$ addition $(-\mathrm{P})$ and $\mathrm{P}$ addition at $100 \mathrm{mg} \mathrm{kg}^{-1}$ as $\mathrm{CaHPO}_{4}(+\mathrm{P})$, and the $\mathrm{P}$ fertilizer was thoroughly mixed in powder form with the 
Table 1. Physicochemical properties of the soil.

\begin{tabular}{lll}
\hline Soil parameters & \\
\hline $\mathrm{pH}$ & 5.21 & \\
Soil organic matter $\left(\mathrm{g} \mathrm{kg}^{-1}\right)$ & 13.36 & 1.10 \\
Olsen $\mathrm{P}\left(\mathrm{mg} \mathrm{kg}^{-1}\right)$ & 19.66 \\
Cation exchange capacity & & \\
$\left(\mathrm{cmol}(+) \mathrm{kg}^{-1}\right)$ & $3.88 \mathrm{~g} \mathrm{~kg}^{-1}$ & \\
Free iron oxide $\left(\mathrm{g} \mathrm{kg}^{-1}\right)$ & $<0.002 \mathrm{~mm}$ & $46.6 \%$ \\
Soil texture & $0.02-0.002 \mathrm{~mm}$ & $24.9 \%$ \\
& $2-0.2 \mathrm{~mm}$ & $28.5 \%$ \\
\hline
\end{tabular}

soil. Soil was then placed in plastic pots $(600 \mathrm{~g}$ capacity) lined with plastic bags.

\section{Plant culture and analysis}

Seeds of three rice (Oryza sativa L.) cultivars, 94D22, KY1360 and YY1 were obtained from Professor Damo Li, Institute of Subtropical Regional Agriculture, Chinese Academy of Sciences. Seeds were disinfected in $30 \%(\mathrm{v} / \mathrm{v}) \mathrm{H}_{2} \mathrm{O}_{2}$ solution for $15 \mathrm{~min}$, followed by thorough washing with de-ionized water. The seeds were germinated in moist Perlite. After 3 weeks, uniform seedlings were selected and two seedlings transplanted into each pot of soil. The pots were randomly arranged in the greenhouse and rearranged several times during the growth period. Each pot was watered with de-ionized water to saturation after transplantation. After initial watering, each pot received $30 \mathrm{ml}$ As-contaminated water $\left(1 \mathrm{mg} \mathrm{kg}^{-1}\right)$ every other day until harvest. The mean growth temperature was $25{ }^{\circ} \mathrm{C}$. The plants were harvested 4 weeks after transplanting.

At harvest, iron plaque on fresh root surfaces was extracted using dithionite-citrate-bicarbonate (DCB) by the method of Taylor and Crowder (1983b) and Otte et al. (1991). The whole root system of each seedling was incubated for $60 \mathrm{~min}$ at room temperature $\left(20-25^{\circ} \mathrm{C}\right)$ in $40 \mathrm{ml}$ of a solution containing $0.03 \mathrm{M}$ sodium citrate $\left(\mathrm{Na}_{3}\right.$ $\mathrm{C}_{6} \mathrm{H}_{5} \mathrm{O}_{7} \cdot 2 \mathrm{H}_{2} \mathrm{O}$ ) and $0.125 \mathrm{M}$ sodium bicarbonate $\left(\mathrm{NaHCO}_{3}\right)$, with the addition of $0.6 \mathrm{~g}$ sodium dithionite $\left(\mathrm{Na}_{2} \mathrm{~S}_{2} \mathrm{O}_{4}\right)$. Roots were rinsed three times with deionized water that was added to the DCB-extracts. The resulting solution was made up to $100 \mathrm{ml}$ with deionized water. After DCB extraction, roots and shoots were oven dried at $70{ }^{\circ} \mathrm{C}$ for 3 days and weighed.

\section{Plant analysis}

Dried plant material was ground and about $0.25 \mathrm{~g}$ weighed accurately into clean, dry digestion tubes $(100 \mathrm{ml})$ (FOSS digestion tube). Concentrated $\mathrm{HNO}_{3}(5 \mathrm{ml})$ was added and allowed to stand overnight. On the following day, the tubes were placed on a heating block (Foss Tecator 2006 Digestion System) and the temperature was raised to $80{ }^{\circ} \mathrm{C}$ for $1 \mathrm{~h}$ and then to $120-130{ }^{\circ} \mathrm{C}$ for $20 \mathrm{~h}$. A reagent blank and standard reference plant material (GBW07605 from the Chinese National Center for Standard Materials) were included to verify the accuracy and precision of the digestion procedure and subsequent analysis. After digestion the solutions were cooled, diluted to $50 \mathrm{ml}$ with ultra-pure water (Easy-pure, Dubugue, Iowa, USA) and filtered into acid-washed plastic bottles. The concentrations of $\mathrm{P}$ and $\mathrm{Fe}$ in the root DCBextracts and the plant acid digests were measured by inductively coupled plasma-optical emission spectrometry (ICP-OES) using a Perkin Elmer Optima 2000 DV and As by atomic fluorescence spectrometry using a Beijing Ruili Analytical Instrument Co. AF-610A, respectively. An internal standard was included and negligible matrix effects were observed for both ICP-OES and atomic fluorescence spectrometry.

\section{Statistical analysis}

All data were subjected to analysis of variance (ANOVA) using the GENSTAT package (Version 6.0, NAG Ltd, England).

\section{Results}

\section{Plant growth}

There were significant differences in both root and shoot biomass among the cultivars and $\mathrm{P}$ treatments (Table 2). Addition of $\mathrm{P}$ fertilizer resulted in a 3-4-fold increase in plant biomass in all three cultivars. Cultivar 94D-22 had the lowest biomass irrespective of $\mathrm{P}$ fertilization.

\section{Plant P concentrations}

The application of $\mathrm{P}$ increased tissue $\mathrm{P}$ concentrations in all cultivars $(P<0.001$, Table 3$)$, with 
Table 2. Shoot and root biomass $\left(\mathrm{g} \mathrm{pot}^{-1}\right)$ of three rice cultivars grown in a low-P soil with or without $\mathrm{P}$ fertilizer.

\begin{tabular}{|c|c|c|c|c|c|c|}
\hline \multirow[t]{2}{*}{ Cultivar } & \multicolumn{3}{|l|}{ Shoot } & \multicolumn{3}{|l|}{ Root } \\
\hline & $-\mathrm{P}$ & & $+\mathrm{P}$ & $-\mathrm{P}$ & & $+\mathrm{P}$ \\
\hline $94 \mathrm{D}-22$ & $0.49 \pm 0.05$ & & $1.64 \pm 0.18$ & $273 \pm 28.5$ & & $517 \pm 18.4$ \\
\hline KY 1360 & $0.62 \pm 0.02$ & & $2.43 \pm 0.06$ & $0.18 \pm 0.02$ & & $0.75 \pm 0.05$ \\
\hline YY1 & $0.61 \pm 0.02$ & & $2.09 \pm 0.10$ & $0.24 \pm 0.02$ & & $0.63 \pm 0.05$ \\
\hline \multicolumn{7}{|c|}{ Analysis of variance } \\
\hline \multicolumn{2}{|l|}{$\mathrm{P}$ treatment $(\mathrm{P})$} & \multicolumn{2}{|l|}{$p<0.001$} & \multicolumn{3}{|c|}{$p<0.001$} \\
\hline \multicolumn{2}{|l|}{ Cultivar (C) } & \multicolumn{2}{|l|}{$p<0.01$} & \multicolumn{3}{|c|}{$p<0.001$} \\
\hline \multicolumn{2}{|l|}{$\mathrm{P} \times \mathrm{C}$} & \multicolumn{2}{|l|}{$p<0.05$} & \multicolumn{3}{|c|}{$p<0.01$} \\
\hline
\end{tabular}

Mean $\pm 1 \mathrm{SD}$

Table 3. $\mathrm{P}$ concentrations in shoot and root $\left(\mathrm{mg} \mathrm{kg}^{-1}\right)$ of three rice cultivars grown on a low-P soil with or without $\mathrm{P}$ fertilizer.

\begin{tabular}{|c|c|c|c|c|c|c|}
\hline \multirow[t]{2}{*}{ Cultivar } & \multicolumn{3}{|l|}{ Shoot } & \multicolumn{3}{|l|}{ Root } \\
\hline & $-\mathrm{P}$ & & $+\mathrm{P}$ & $-\mathrm{P}$ & & $+\mathrm{P}$ \\
\hline 94D-22 & $495 \pm 11.6$ & & $865 \pm 13.8$ & $273 \pm 28.5$ & & $517 \pm 18.4$ \\
\hline KY1360 & $448 \pm 10.1$ & & $784 \pm 26.2$ & $312 \pm 28.2$ & & $438 \pm 10.8$ \\
\hline YY1 & $489 \pm 11.3$ & & $968 \pm 63.9$ & $284 \pm 16.8$ & & $493 \pm 26.6$ \\
\hline \multicolumn{7}{|c|}{ Analysis of variance } \\
\hline \multicolumn{2}{|l|}{$\mathrm{P}$ treatment $(\mathrm{P})$} & \multicolumn{2}{|l|}{$p<0.001$} & \multicolumn{3}{|c|}{$p<0.001$} \\
\hline \multicolumn{2}{|l|}{ Cultivar (C) } & \multicolumn{2}{|l|}{$p<0.05$} & \multicolumn{3}{|c|}{ NS } \\
\hline \multicolumn{2}{|l|}{$\mathrm{P} \times \mathrm{C}$} & \multicolumn{2}{|l|}{ NS } & \multicolumn{3}{|c|}{$p<0.05$} \\
\hline
\end{tabular}

Mean \pm 1 SD.

shoot $\mathrm{P}$ concentrations roughly doubling with $\mathrm{P}$ application compared with the control treatment, and root $\mathrm{P}$ concentrations increasing to a lesser extent with $\mathrm{P}$ application. There were significant differences in shoot $\mathrm{P}$ concentration between cultivars but differences in root $\mathrm{P}$ concentration were marginal, possibly due to the large variation between replicates.

Iron plaque formation and $P$ and As concentrations in iron plaque

Roots of all plants appeared reddish at harvest, indicating the formation of iron plaque on the root surface. Addition of $\mathrm{P}$ fertilizer decreased the amounts of iron plaque (DCB-extractable Fe, DCB-Fe hereafter) on the root surface $(P<0.001$, Figure 1$)$, and with $\mathrm{P}$ fertilization the amounts of iron plaque were less than half of those without $\mathrm{P}$ fertilization. There were significant dif- ferences between cultivars in the amounts of iron plaque, with cultivar 94D-22 having the most and KY136 having the smallest amount of iron plaque irrespective of $\mathrm{P}$ fertilization, although the differ-

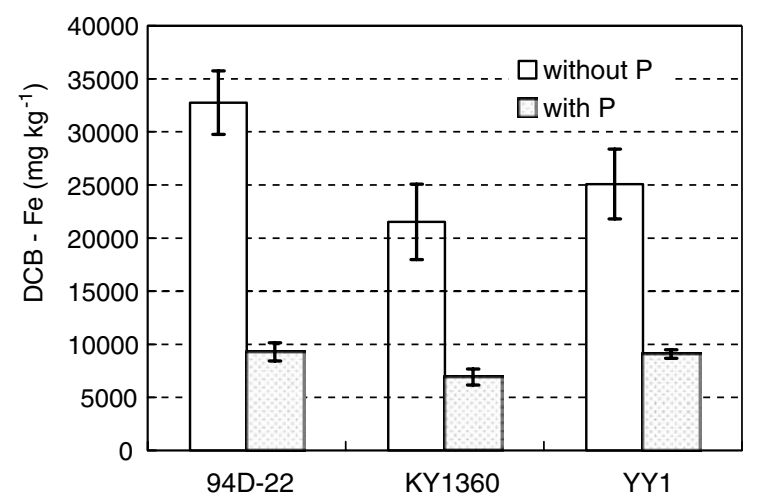

Fig. 1. DCB-extractable Fe concentration on the roots of three rice cultivars grown on a low-P soil with or without $\mathrm{P}$ fertilizer. Bars: $\pm 1 \mathrm{SD}$ 
ence in the zero-P controls was rather small (albeit statistically significant).

Concentrations of $\mathrm{P}$ associated with iron plaque (DCB-extractable P, DCB-P hereafter) were much lower with $\mathrm{P}$ fertilization than without $\mathrm{P}(P<0.001$, Figure 2). There were significant differences among cultivars in DCB-P. Concentrations of As associated with iron plaque (DCB-extractable As, DCB-As hereafter) were significantly lower with $\mathrm{P}$ fertilization than without P (Figure 3). Cultivar 94D-22 had the highest amounts of DCB-As irrespective of P fertilization.

\section{Tissue as concentrations}

P fertilization did not have any significant effect on shoot As concentrations (Table 4) but there were significant differences among cultivars, with

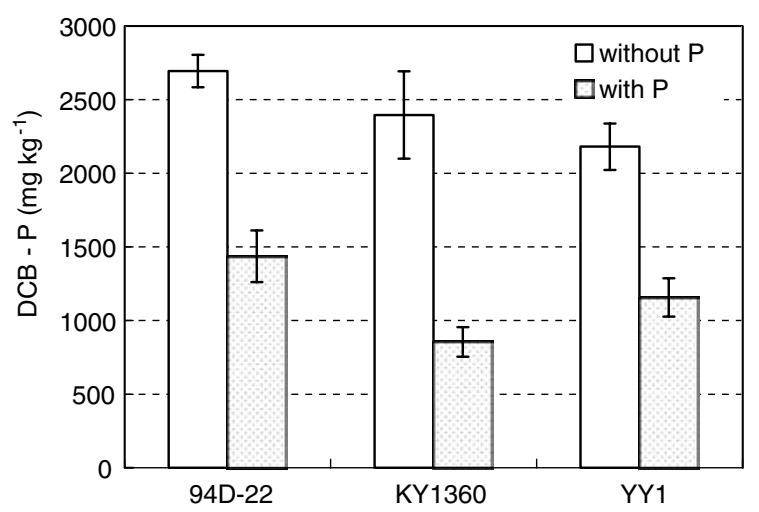

Fig. 2. DCB-extractable $\mathrm{P}$ concentration on the roots of three rice cultivars grown on a low-P soil with or without $\mathrm{P}$ fertilizer. Bars: \pm 1 SD.

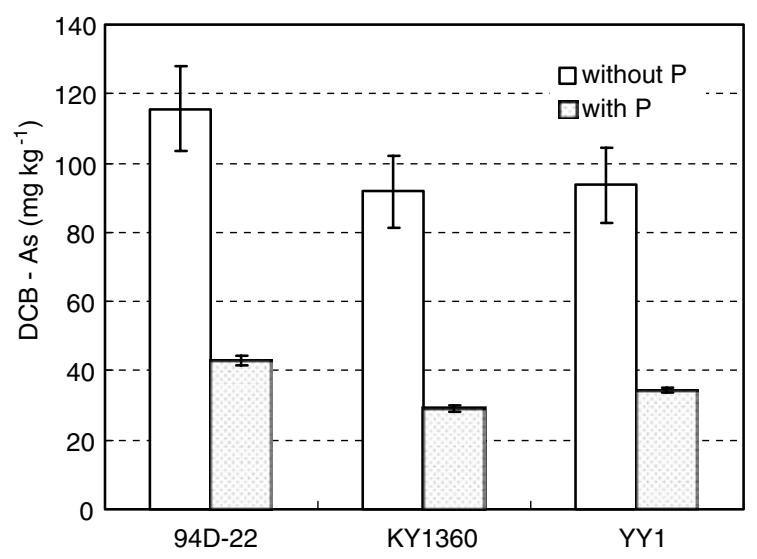

Fig. 3. DCB-extractable As concentration on the roots of three rice cultivars grown on a low-P soil with or without $\mathrm{P}$ fertilizer. Bars: \pm 1 SD.

cultivar KY1360 always having the lowest shoot As concentration irrespective of $\mathrm{P}$ fertilization. Concentrations of As in roots of cultivars 94D-22 and YY1 were significantly lower with P fertilization than without $\mathrm{P}$ fertilization, but $\mathrm{P}$ fertilization had no effect on root As concentrations in cultivar KY1360. No significant differences in As concentrations of roots were observed between the three cultivars.

\section{Discussion}

The soil used in the present study was very low in $\mathrm{P}$ (Table 2) and without $\mathrm{P}$ fertilization plant growth was severely restricted, with tissue $\mathrm{P}$ concentrations being well below optimum levels (Marschner 1995). Even with the P fertilization,

Table 4. As concentrations in shoot and root $\left(\mathrm{mg} \mathrm{kg}^{-1}\right)$ of three rice cultivars grown on a low-P soil with or without $\mathrm{P}$ fertilizer.

\begin{tabular}{|c|c|c|c|c|c|c|}
\hline \multirow[t]{2}{*}{ Cultivar } & \multicolumn{3}{|l|}{ Shoot } & \multicolumn{3}{|l|}{ Root } \\
\hline & $-\mathrm{P}$ & & $+\mathrm{P}$ & $-\mathrm{P}$ & & $+\mathrm{P}$ \\
\hline $94 \mathrm{D}-22$ & $1.16 \pm 0.10$ & & $1.23 \pm 0.32$ & $7.52 \pm 1.89$ & & $2.74 \pm 0.36$ \\
\hline KY1360 & $0.85 \pm 0.12$ & & $0.68 \pm 0.11$ & $4.81 \pm 0.66$ & & $4.34 \pm 1.18$ \\
\hline YY1 & $1.04 \pm 0.18$ & & $1.01 \pm 0.11$ & $7.55 \pm 1.27$ & & $2.31 \pm 0.24$ \\
\hline \multicolumn{7}{|c|}{ Analysis of variance } \\
\hline \multicolumn{2}{|c|}{$\mathrm{P}$ treatment $(\mathrm{P})$} & \multicolumn{2}{|l|}{$p=0.05$} & \multicolumn{3}{|c|}{$p<0.01$} \\
\hline \multicolumn{2}{|l|}{ Cultivar (C) } & \multicolumn{2}{|l|}{ NS } & \multicolumn{3}{|c|}{ NS } \\
\hline \multicolumn{2}{|l|}{$\mathrm{P} \times \mathrm{C}$} & \multicolumn{2}{|l|}{ NS } & \multicolumn{3}{|c|}{ NS } \\
\hline
\end{tabular}

Mean \pm 1 SD. 
tissue $\mathrm{P}$ concentrations were at the lower end of normal range for plant tissues. In accordance with our previous results (Liu et al. 2004a), low P conditions enhanced the formation of iron plaque as there was an almost two-fold increase in the amounts of iron plaque (DCB-Fe) under low $\mathrm{P}$ level compared to high $\mathrm{P}$ level in the soil (Figure 1). Despite the low $\mathrm{P}$ level in the nonfertilized soil, concentrations of DCB-P were much higher than in the P-amended soil, and the concentrations of DCB-P were highly correlated with the amounts of iron plaque (Figure 4). This strongly indicates that the iron plaque was a major factor controlling $\mathrm{P}$ deposition on the root surface. It is well known that phosphate has a high affinity for iron oxide surfaces, thus iron plaque on the root surface may sequestrate phosphate, and act as a 'buffer' for P in the soil-plant system.

In this study the soil was irrigated with As (V)contaminated water, and a substantial proportion of As would have remained as As (V) despite the flooded conditions during the experimental period due to the oxidizing status of the rhizosphere (Belzile \& Tessier 1990; Abedin et al. 2002). Both As (V) and As (III) may be adsorbed (sequestrated) by the iron plaque on the root surface. A linear relationship between DCB-Fe and DCB-As was also observed (Figure 5). Although it has been shown that As in the form of arsenate has a higher affinity for iron oxide than phosphate (Meng et al. 2002), P concentrations in the soil solution were presumably much higher than those of As, therefore As concentration in the iron plaque was much lower than those of P. Nevertheless, despite the high $\mathrm{P}$ concentration in the soil with $\mathrm{P}$ fertilization, there was only a marginal difference in the

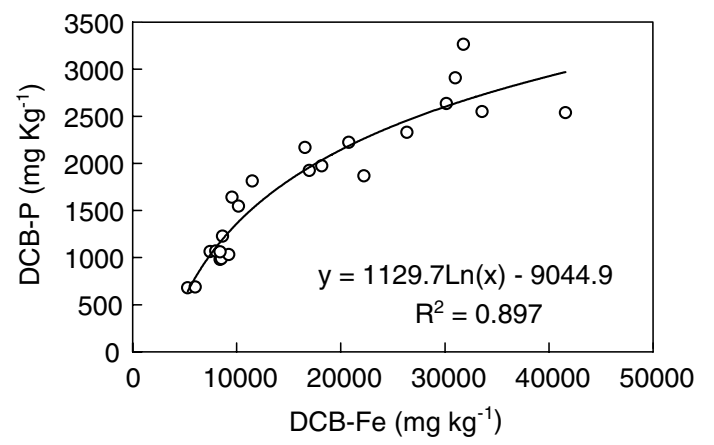

Fig. 4. Relationship between concentrations of DCB-extractable $\mathrm{P}$ and DCB-extractable $\mathrm{Fe}$ in the roots of three rice cultivars grown on a low-P soil with or without $\mathrm{P}$ fertilizer.

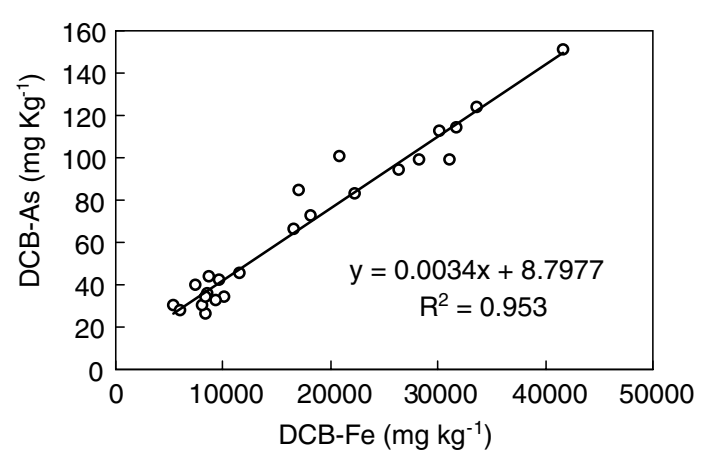

Fig. 5. Relationship between concentrations of DCB-extractable As and DCB-extractable Fe in the roots of three rice cultivars grown on a low-P soil with or without $\mathrm{P}$ fertilizer.

ratio of DCB-Fe to DCB-As, indicating a strong association between As and iron plaque (data not shown). Due to the strong As sequestration in iron plaque, DCB-As was 10 to 100 times higher than As concentration in the plant tissues (Table 4 and Figure 3).

It has been shown that As (V) uptake by various plants is through high-affinity phosphate transporters because arsenate and phosphate are analogous (Meharg \& Macnair 1990) and As (V) uptake by rice was shown by Abedin et al. (2002) to be inhibited by P. In this study it seems to show that $\mathrm{P}$ fertilization significantly reduced As concentrations in the roots, and the higher As concentrations in the roots in the zero-P treatment may be partly due to residual As on the root surface following extraction with DCB. Despite the significantly higher concentrations of As in roots and in DCB-extracts in the zero-P treatment, difference in shoot As concentrations was not observed. These results indicate that iron plaque may restrict the translocation of As from roots to shoots, and confirm our previous finding that the formation of iron plaque may alter the interactions between $\mathrm{P}$ and As in soil-rice plant systems (Liu et al. 2004a). However, the quantitative relationships between $\mathrm{P}$ nutrition, and As accumulation in iron plaque on rice roots remain unclear, and further investigation is warranted.

\section{Acknowledgements}

This study was supported by the Ministry of Science and Technology (2002CB410808) and the Natural Science Foundation of China (40225002). 


\section{References cited}

Abedin MJ, Cotter-Howells J, Meharg AA. 2002 Arsenic uptake and accumulation in rice (Oryza sativa) irrigated with contaminated water. Plant and Soil 240, 311-319.

Abedin MJ, Feldmann J, Meharg AA. 2002 Uptake kinetics of arsenic species in rice plants. Plant Physiol 128, 1120-1128.

Bacha RE, Hossner LR. 1977 Characteristics formed on rice roots as affected by Fe and Mn additions. Soil Sci Soc Am J 41, 931-935.

Biswas BK, Dhar RK, Samanta G, et al. 1998 Detailed study report of Samta, one of the arsenic affected village of Jessore District, Bangladesh. Curr Sci 74, 134-145.

Belzile N, Tessier A. 1990 Interactions between arsenic and iron oxyhydroxides in laustrine sediments. Geochim Cosmochim Acta 54, 103-109.

Chen CC, Dixon JB, Turner FT. 1980 Iron coatings on rice roots: morpology and models of development. Soil Sci Soc Am J 44, 1113-1119.

Chen SL, Yeh SJ, Yang MH, Lin TH. 1995 Trace-element concentration and arsenic speciation in the well water of a Taiwan area with endemic blackfoot disease. Biol Trace Element Res 48, 263-274.

Chowdhury TR, Basu GK, Mandal BK. et al. 1999 Arsenic poisoning in the Ganges delta. Nature 401, 545-546.

Dey MM, Miah MNI, Mustafi BAA, Hossain M. 1996 Rice production constraints in Bangladesh: implications for further research priorities. In Evenson RE, Herdt RW, Hossain M, (eds) Rice Research in Asia: Progress and Priorities. Manila, Philippines: CAB International, Wallingford, UK and International Rice Research Institute. pp. 179-191.

Dhar RK, Biswas BK, Samanta G. 1997 Groundwater arsenic calamity in Bangladesh. Curr Sci 73, 48-59.

Galbraith H, Lejeune K, Lipton J. 1995 Metal and arsenic impacts to soils, vegetation communities, and wildlife habitat in southwest Montana uplands contaminated by smelter emissions: I. Field evaluation. Environ Toxicol Chem 14, 1895-1903.

Greipsson S, Crowder AA. 1992 Amelioration of copper and nickel toxicity by iron plaque on roots of rice (Oryza sativa). Can J Bot 70, 824-830.

Greipsson S. 1994 Effects of iron plaque on roots of rice on growth and metal concentration of seeds and plant tissues when cultivated in excess copper. Commun Soil Sci Plant Anal 25, 2761-2769.

Greipsson S. 1995 Effect of iron plaque on roots of rice on growth of plants in excess zinc and accumulation of phosphorus in plants in excess copper or nickel. J Plant Nutr 18, 1659-1665.

Huang YZ, Qian XC, Wang GQ, et al. 1992 Syndrome of endemic arsenism and fluorosis: a clinical study. Chinese Med $J$ 105, 586-590.

Juhsz AL, Naidu R, Zhu YG, Wang LS, Jiang JY, Cao ZH. 2003 Toxicity issues associated with geogenic arsenic in the groundwater-soil-plant-human continuum. Bull Environ Contamin Toxicol 71, 1100-1107.

Kuo S. 1986 Concurrent sorption of phosphate and zinc, cadmium, or calcium by a hydrous ferric oxide. Soil Sci Soc Am J 50, 1412-1419.
Liangfang W, Jinghong H. 1994 Chronic arsenism from drinking water in some areas of Xinjiang, China. In: Nriagu JO, ed. Arsenic in the Environment, Part II: Human Health and Ecosystem effects. New York NY: John Wiley \& Sons Inc., pp. 159-172.

Lin KF, Xu XQ, Paul A, Xiang YL, Jin X. 2001 Relationship between As contents of farmers' hair and of environment in As polluted area. Chinese Environ Sci 21, 440-444.

Liu WJ, Zhu YG, Smith FA, Smith SE. 2004a Do phosphorus nutrition and iron plaque alter arsenate (As) uptake by rice seedlings in hydroponic culture? New Phytol 162, 481-488

Liu WJ, Zhu YG, Smith FA, Smith SE. 2004b Do iron plaque and genotypes affect arsenate uptake and translocation by rice seedlings (Oryza sativa L.) grown in solution culture? $J$ Exp Bot 55, 1707-1703.

Lu RK. 1999 Analytical Methods for Soils and Agricultural Chemistry. Beijing, China: China Agricultural Science and Technology Press.

Maclean KS, Langille WM. 1981 Arsenic in orchard and potato soils and plant tissue. Plant Soil 61, 413-418

Mandal BK, Chowdhury TR, Samanta G, et al. 1996 Arsenic in groundwater in seven districts of west Bengal, India: the biggest arsenic calamity in the world. Curr Sci 70, 976-986.

Mandal BK, Chowdhury TR, Samanta G, et al. 1997 In reply to "chronic arsenic toxicity in West Bengal." Curr Sci 72, 114-117.

Marschner H. 1995 Mineral Nutrition of Higher Plants, 2nd edn. London, UK: Academic Press Ltd.

Meharg AA. 2004 Arsenic in rice - understanding a new disaster for South-East Asia. Trends Plant Sci (in press).

Meharg AA, Macnair MR. 1990 An altered phosphate uptake system in arsenate tolerant Holcus Lanatus. New Phytol 116, 29-35.

Meng XG, Korfiatis GP, Bang S, Bang KW. 2002 Combined effects of anions on arsenic removal by iron hydroxides. Toxicol Lett 133, 103-111.

Nickson R, McArthur J, Burgess W, Ahmed KM, Ravenscroft P, Rahman M. 1998 Arsenic poisoning in Bangladesh groundwater. Nature 395, 338-338.

Smith AH, Hopenhaynrich C, Bates MN, et al. 1992 Cancer risks from arsenic in drinking water. Environ Health Perspect 97, 259-267

Otte ML, Dekkers MJ, Rozema J, Broekman RA. 1991 Uptake of arsenic by Aster tripolium in relation to rhizosphere oxidation. Can J Bot 69, 2670-2677.

Otte ML, Rozema J, Koster L, Haarsma MS, Broekman RA. 1989 Iron plaque on roots of Aster tripolium L.: interaction with zinc uptake. New Phytol 111, 309-317.

Otte ML, Buijs EP, Riemer L, Rozema J, Broekman RA. 1987 The iron plaque on roots of salt marsh plants: a barrier to heavy metal uptake? Proceedings of the International Conference Heavy Metal in the Environment, New Orleans (USA) I, CEP Consultants, Edinburgh, pp. 407-409.

Taylor GJ, Crowder AA. 1983a Uptake and accumulation of heavy metals by Typha latifolia L. in wetlands of Sudbury, Ontario region. Canad. J Bot 61, 63-73.

Taylor GJ, Crowder AA. 1983b Use of DCB technique for extraction of hydrous iron oxides from roots of wetland plants. Am J Bot 70, 1254-1257. 


\section{Y. HU ET AL.}

Ullah SM. 1998 Arsenic contamination of groundwater and irrigated soils of Bangladesh. Abstracts: International Conference on Arsenic Pollution of Groundwater in Bangladesh: Causes, Effects and Remedies, 8-12 February 1998. Dhaka Community Hospital, Dhaka, Bangladesh, pp. 133.

Wang TG, Peverly JH. 1999 Iron oxidation states on root surfaces of a wetland plant (Phragmites australis). Soil Sci Soc Am J 63, 247-252.

Xie ZM, Huang CY. 1998 Control of arsenic toxicity in rice plants grown on an arsenic-polluted paddy soil. Commun Soil Sci Plant Anal 29, 2471-2477.
Yan CH. 1994 Arsenic distribution in soils. In: Nriagu JO, ed. Advances in Environmental Science and Technology, Arsenic in the environment. Part I: Cycling and characterization. New York, USA: John Wiley \& Sons Inc., pp. 17-49.

Ye ZH, Baker AJM, Wong MH, Willis AJ. 1998 Zinc, lead and cadmium accumulation and tolerance in Typha latifolia as affected by iron plaque on the root surface. Aquat Bot 61, 5567.

Zhang XK, Zhang FS, Mao DR. 1998 Effect of iron plaque outside roots on nutrient uptake by rice (Oryza sativa L.): zinc uptake by Fe-deficient rice. Plant and Soil 202, 33-39. 